Wedgwood's Portrait Medallions of Men of Science

Is his Friday evening discourse before the Royal Institution on December 16, Dr. John Thomas spoke on "Josiah Wedgwood and his Portraits of Eighteenth Century Men of Science". The great success of three fellows of the Royal Society-Josiah Wedgwood and his two friends Matthew Boulton and James Watt-as industrialists was discussed. The successful production of artistic pottery at Etruria and of steam engines at Soho Factory, was only possible because of the persistent application of scientific principles. These 'philosophic' fellow. manufacturers endeavoured to satisfy this craving for scientific knowledge by attaching themselves to (a) the Lunar Society in the Midlands and (b) the Royal Society of London. Josiah Wedgwood, because of the artistic character of his jasper portrait medallions in the days before photography, established himself practically as the 'official' portrait producer of learned societies. Proof of this is the assembly of more than one hundred portrait medallions in Dr. Thomas's collection. Wedgwood handed the torch of science to his descendants, among whom was the illustrious Charles Darwin, his grandson, of whom Dr. Thomas exhibited a fine plaque by Wedgwood. Thus we, who live in the twentieth century, owe a great debt of gratitude to the 'prince of potters', not only for his scientific outlook, but also for the light which he has shed on his scientific contemporaries, through his inimitable portrait medallions.

\section{Earthquake in Spain}

AN earthquake was experienced in Spain on December 13, shaking the whole province of Valencia. The shock, which lasted three seconds, caused some apprehension and damaged buildings, but no casualties are reported. The district concerned is to some extent seismically active, as it borders the wellestablished Mediterranean region of earthquake activity, though it is not so densely populated with epicentres as is the region of Andalusia and Granada to the south of it. No really great earthquake has been experienced nearer to this region than Lisbon, 475 miles distant. It was from the Lisbon epicentre that the three shocks and several aftershocks occurred on and after November 1, 1755, at 9 h. $40 \mathrm{~m}$. local time. The first lasted seven minutes, destroyed Lisbon and caused remarkable sea-waves in such distant regions as Scotland and Sweden. The second at $10 \mathrm{~h}$. engulfed the Cays Depreda with the people on it and the vessels near it so that none of them were seen again, and altogether upwards of fifty thousand people lost their lives on that occasion.

\section{New Merseyside Nature Society}

Followne an inaugural field-meeting at Freshfield dunes and shore on December 11, a new nature study society for south-west Lancashire and Wirral was launched, as the Merseyside Branch of the British Empire Naturalists' Association, when the following officials were elected for 1939: Hon. President, $J$. W. Nixon (who is the Ribble Valley representative of the B.E.N.A. and honorary secretary of the Blackburn Naturalists' Field Club); Chairman, J. C. Miller, of the University of Liverpool; Hon. Organizing Secretary, Eric Hardy. It was announced that the new Merseyside Naturalists' Association would eover the area between the Ribble and the Dee on a much more modern and active method of general field nature study than was at present available in the area, although it was in no way antagonistic to some ten older natural history societies in the district. Mr. Hardy stated that the Society had been formed by about fifty naturalists and nature-lovers who had given their signatures to the desire for introducing the B.E.N.A. work to Merseyside. It was agreed that in 1939 they report on their area for the national bird survey being carried out by the scientific committee of the British Trust for Ornithology, and for the selected list of trees and insects chosen for national observation by the B.E.N.A. headquarters. Arrange. ments had been made for combination with the branches of the B.E.N.A. for Manchester and West Lancashire (Lytham).

\section{The Parliamentary Science Committee}

THE fifth annual meeting of the Parliamentary Science Committee was held at the House of Commons on December 13, under the presidency of Prof. J. Graham Kerr. The honorary secretary's report disclosed that the Committee's constituent bodies now number twenty-six, five of which have become affiliated during the past twelve months. Three peers and fourteen Members of Parliament are now associated with the executive, with the result that the Parliamentary activities of the Committee have greatly extended. Interventions in debate on the initiative of the Committee were frequent last session; more than thirty questions were asked in the House of Commons on scientific and technical matters; and during the current session it is hoped that members will be fortunate in the ballot for private members' motions. The Committee has been associated with Parliamentary action on the Thames barrage and the removal of the oil tanker limits on the Thames. Negotiations are on foot to establish complete liaison with the new Division for the Social and International Relations of Science of the British Association. Two lectures were arranged during the last session at the House of Commons for Members of Parliament. The following were elected officers for 1939 : President, the Right Hon. the Earl of Dudley; Vice-President, Sir Arnold Wilson, M.P.; Chairman, Mr. S. F. Markham, M.P. ; Vice-Chairman, Prof. B. W. Holman; Deputy-Chairman, Mr. Alan E. L. Chorlton, M.P.; and Hon. Secretary and Treasurer, Mr. H. W. J. Stone.

\section{The Cultural Influence of the Cinema}

The League of Nations Advisory Committee on Social Questions has issued a report, based on information collected from the Governments of forty-six countries and from other sources, on "The Recreational Cinema and the Young" (London: Allen and Unwin. Pp. 32. Price 9d.). It discusses the frequency of the attendance of young people at cinema theatres, the effects of attendance, juvenile taste in films, protection from unsuitable films, teaching of film 